\title{
Convergence on the Council Opinions of 2007 in Japan
}

\author{
Yanhong Pang \& Daojin Shi \\ School of Economics and Management, Zhejiang Forestry University \\ Lin'an 311300, China \\ E-mail: pyh166@126.com
}

This research paper was Supported by Startup Foundation for Introducing Talents of Zhejiang Forestry University and Institute of Accounting of Zhejiang Forestry University.

\begin{abstract}
In order to improve the effectiveness of internal control, the Business Accounting Council (BAC) established the Subcommittee which held 16 special meetings to discuss and develop a set of standards of internal control for Japan from February 2005 to January 2007. The BAC did not finalize the Council Opinions of 2007 until February 15, 2007. Based on the minutes of the Subcommittee meetings, this paper mainly traces the process of establishing the standards and practice standards for management assessment and audit concerning internal control over financial reporting, focusing on the changes of standards in the setting process. The history of internal control is also briefly reviewed in this paper.
\end{abstract}

Keywords: Internal control over financial reporting, Management assessment and audit concerning, Council opinions

\section{Simple Review of Internal Control in Japan}

\subsection{Research on Internal Control over Financial Reporting}

Based on the postwar securities democratization, the newly formed Japanese accounting profession was very weak on the research of auditing on the side of Certified Public Accountants (CPAs). It did not clarify what internal control was from researcher's standpoint until 1970, the Special Committee of Japanese Accounting Association (Special Committee) issued the report titled "Research on Internal Control over Financial Reporting". In this report, internal control was defined as a generic term of system, organization, method and procedure which was set by the management in order to safeguard assets, assure the accuracy and reliability of the accounting record, and to generally plan, adjust and evaluate the management activities. This definition shows that the objectives of internal control were (1) to safeguard assets which belongs to asset management, (2) to assure the accuracy and reliability of the accounting record which refers to accounting management, (3) to make the management activities effective and efficient which relates to process management. Thus the internal control that should be evaluated by the auditor of financial statements audit was divided into asset management and accounting management. This classification was consistent with that of AICPA at that time. However, the Special Committee could not distinct control from management since it used "management" but not "control" in this definition.

\subsection{Auditing Standards related to Internal Control}

In response to the dramatically changing of auditing environment, in December, 1991, the revised Auditing Standards, Working Rules of Audit Procedures of Field Work and Working Rules of Audit Procedures in Reporting (ASh3) were issued. It was for the first time that Japanese auditing standard-setting body, the Business Accounting Council (BAC) of the Ministry of Finance (MOF), introduced a new concept of internal control and the risk approach. As a standard of field work [Section 3], ASh3 stipulated that when planning the audit and determining the audit procedure, timing, and the extent of tests to be performed, the auditor should obtain a sufficient understanding of internal control, and fully consider the materiality of audit object, audit risk and other factors. ASh3 also addressed the working rules of audit procedure of field work [Section 5] when the auditor made an audit planning and evaluated the effectiveness of internal control and the audit risk. The risk approach was reconfirmed by the revised auditing standards in 2002 (ASh14) and developed in the revised auditing standards in 2005 (ASh17). ASh14 explicitly prescribed three components (inherent 
risk, control risk and detection risk) of audit risk and their relationship. ASh17 combined inherent risk and control risk into material misstatement risk.

\subsection{Necessity for Improvement of Internal Control}

In the United States, the importance of companies' internal controls has been widely recognized since a series of misconducts occurred in the United States such as the Enron case. To enhance the effectiveness of the internal control, Public Company Accounting Reform and Investor Protection Act of 2002 (Sarbanes-Oxley Act of 2002) was issued and the management of the Securities and Exchange Commission (SEC) registrant were required to prepare the internal control report, in which an assessment of the effectiveness of the internal control over financial reporting became an important part. Moreover, each registrant was subject to an audit by certified public accountants.

In Japan, improper practices (e.g., the representative suit against Kobe Steel in 2002 and the Kanebo accounting fraud of 2004) have also been observed recently concerning corporate information disclosure under the Securities and Exchange Law, especially in the annual report. These may indicate that the function of internal control to ensure the reliability of corporate disclosure worked ineffectively. As is well known, the securities market cannot fulfill its function perfectly unless corporate information is fairly disclosed to the investors. Thus, it is necessary to enhance the effectiveness of internal control.

\section{Toward Exposure Draft of Standards for Management Assessment and Audit concerning Internal Control over Financial Reporting}

\subsection{Process of Exposure Draft of Standards}

The development of the standard of the assessment by management and audit by the auditor on the effectiveness of internal control over financial reporting came to the agenda of a general meeting of the BAC in January 2005. One of the most important contents of the general meeting was to discuss the effectiveness of internal control and establish the Internal Control Subcommittee (Subcommittee) (Note 1). Discussions started from February 2005 in the first meeting of the Subcommittee. Based on the second and third Subcommittee meetings' reviewing the existing internal control standards of other countries, the Subcommittee put forward the key points of setting assessment and auditing standards of internal control over financial reporting in the $4^{\text {th }}$ meeting and formed the "Preliminary Draft: Standards of for Management Assessment and Audit concerning Internal Control Over Financial Reporting" (Preliminary Draft) in following four Subcommittee meetings. After considering the statement of witness's opinions (the $9^{\text {th }}$ meeting) and the discussions in the Subcommittee meetings, the Subcommittee revised the Preliminary Draft of Standards (the $10^{\text {th }}$ meeting) and formed Exposure Draft of Standards (the $11^{\text {th }}$ meeting). The proceeding toward Exposure Draft Standards can be seen in table 1 .

\subsection{Key Points of Setting Assessment and Audit Standards of Internal Control over Financial Reporting}

In the $4^{\text {th }}$ Subcommittee meeting, Tagaya [2005], the director for financial accounting, introduced the key points of setting assessment and audit standards of internal control over financial reporting which are summarized in table 2. 17 key points covering framework of internal control, assessment and audit of internal control and report of assessment and audit were discussed in the meeting.

Insert Table 1 here

\subsection{Preliminary Draft of Standards of Internal Control over Financial Reporting}

Based on the framework of COSO report, discussions and opinions of the Subcommittee meetings, three parts of Preliminary Draft of Standards were formed and discussed in the $5^{\text {th }}, 6^{\text {th }}$ and $7^{\text {th }}$ Subcommittee meeting respectively. The summary of the three parts revised according to the opinion formed in the meeting composed of the whole Preliminary Draft of Standards in the $8^{\text {th }}$ meeting. The following issues were main focuses in the discussion.

\section{Basic Framework of Internal Control}

In the $5^{\text {th }}$ meeting, internal control was defined as a process and system set and operated by board of directors, management and others in the organization and incorporated in its operating activities in order to provide reasonable assurance of achieving four objectives: effectiveness and efficiency of business operations, reliability of financial reporting, compliance with applicable laws and regulations relevant to business activities, and safeguarding of assets. Internal control consisted of six basic components: control environment, risk assessment and response, control activities, information and communication, monitoring, and control using information technology (IT control).

It pointed out that internal control was a process and a system within the organization which was similar to the definition in the COSO report. It also extended the COSO report in the objectives and components. Based on the Japan's condition, it added safeguarding of assets and control using information technology (IT control) as the appropriate objective and component for Japan. Safeguarding of assets was first described to prevent or detect the illegal acquisition, use, and the disposal of the property. IT control was divided into company-level control and 
process-level control. However, the components were not included in the definition of internal control in the $5^{\text {th }}$ meeting.

Insert Table 2 here

According to the opinion that received from the Subcommittee meetings, the Revised Preliminary Draft of Standards which was discussed in the $8^{\text {th }}$ meeting changed in the following aspects. In consideration of the description that "illegal acquisition..." in the safeguarding of assets might result in misunderstanding, the Revised Preliminary Draft of Standards revised "illegal" into "unauthorized". To enhance the understanding of reliability of financial reporting, the scope was expanded to ensure the reliability of financial statements and the information that could have a material effect on financial statements. It added a new section titled "Positioning of the Framework" which included the sections of the relationship between objectives and components of internal control and the limitations of internal control that were addressed in the $5^{\text {th }}$ meeting, and added the section of "Roles and Responsibilities of Relevant Persons", such as management, board of directors, and the like. The section of "Internal Control Documentation" and the section of "Internal Control over Financial Reporting and Its Effectiveness" were deleted.

\section{Assessment and Report on Internal Control over Financial Reporting}

The sixth meeting introduced and discussed assessment and report on internal control over financial reporting, including relevant definitions, scope and method of assessment, and management's report on internal control over financial reporting. It clarified that management had the role and responsibility to design and operate internal control as well as assess the effectiveness of internal control over financial report on the consolidated bases and report its conclusion externally in order to ensure the reliability of financial reporting. In the reasonable scope, management should first assess the company-level control and, based on the result, assess process-level control.

No significant changes were found in the Revised Preliminary Draft of Standards. Aiming at the censure that it was difficult to understand the effectiveness of internal control, the Revised Preliminary Draft of Standards explained that the effectiveness of internal control over financial reporting signified an internal control that was designed and operated in accordance with an appropriate internal control framework and was free of material weakness. The material weakness was a deficiency that had a reasonable possibility of material effect on financial reporting. In short, it was clarified that the effectiveness of internal control was free of material weakness. To define the effectiveness of internal control and the material weakness respectively was conducive to removing the misunderstanding of the deficiency of internal control and material weakness (Note 2). On the supplementary information of the management's report, instead of the description of "subsequent events" in the sixth meeting, the Preliminary Draft of Standards addressed that (1) subsequent events that would have a material impact on assessments of the effectiveness of internal control over financial reporting and (2) remediation and other matters pertaining to material weakness implemented after the end of the fiscal year. It specified the items of supplementary information and was consistent with statement of the remediation of material weakness in internal control in method of assessing internal control over financial reporting.

\section{Audit of Internal Control over Financial Reporting}

The audit on internal control over financial reporting was discussed in the $7^{\text {th }}$ Subcommittee meeting in the following aspects: (1) objective of the internal control audit by financial statement auditors, (2) relationship between the internal control audit and the financial statement audit, (3) performance of the internal control audit, and (4) auditor's report. It required that the external auditors of financial statements should audit internal control report by management and express their opinions in the auditor's report on whether the management's internal control report fairly stated the result of the assessment.

The contents discussed in the $8^{\text {th }}$ meeting varied as follows. On the objective of the internal control audit by financial statement auditors, the Revised Preliminary Draft of Standards emphasized that it must be mindful of not burdening excessively when the auditor thought about a specific procedure. The Revised Preliminary Draft of Standards mentioned that the internal control audit and financial statement audit, taken as a whole, should be performed by the same external auditor. Further, the same external auditor was clarified in the note that it meant not only the same audit firm but also the same engagement partner that conducted the audit. The modification of the auditor's report was mainly presented in the description of auditor's opinion. The Revised Preliminary Draft of Standards added the treatment under the condition that the internal control report by management included a material weakness in internal control over financial reporting and reasons why they had not been remedied. On such cases, when the auditor concluded these statements were fairly stated and therefore expressed an unqualified opinion, the external auditor must include the information in the internal control audit report on the material weakness and the reason why it has not been remedied. On the contrary, when the auditor concluded that they were not fairly stated, the auditor should express adverse opinion. The inappropriateness and the reasons should be included in the internal control audit report. The section of "Disclaimer Opinion" was deleted. In accordance with assessment and report on internal control over financial reporting, the contents of additional information were revised to (1) subsequent events that would have a material impact on 
assessments of the effectiveness of internal control over financial reporting and (2) remediation and other matters pertaining to material weakness implemented after the end of the fiscal year.

\subsection{Exposure Draft of Standards}

Considering statement of witness's opinion(Note 3), the Revised Preliminary Draft of Standards was revised in the tenth and eleventh Subcommittee meetings. On July 13, 2005, the FSA issued "Exposure Draft of Standards for Management Assessment and Audit concerning Internal Control over Financial Reporting" to request public comment, which composed of the Revised Preliminary Draft and a preface. The preface described the general background of discussions, structure and contents of the standards, etc. The Exposure Draft of Standards established the basic structure of the standard of internal control over financial reporting and laid a good foundation for the formal standards.

Table 3 shows the outline of the Exposure Draft of Standards. Compared to the Revised Preliminary Draft of Standards which was discussed in the 8th Subcommittee meeting, the Exposure Draft of Standards mainly varied in the following aspects.

Changes of "I Basic Framework of Internal Control". On the objective of internal control, based on the opinion of Member Yagi and Task Force Member Suzuki, safeguarding of assets was revised to ensure that assets were acquired, used and disposed of in accordance with proper procedure and approvals. Thus, it can prevent the acquirement, use and disposal of assets from improper procedure and disapprovals. In order to clarify the abstract theory, the Exposure Draft of Standards gave some illustrations for every component of internal control in the note. The section of "Positioning of the Framework in the Preliminary Draft of Standards" was reorganized as three sections. The relationship between objective and basic components and a new part were recognized as section of "I 3 Design and Operation of Internal Control". The new part mainly addressed that in order to achieve the objective of internal control, management should manage to design and operate internal control system in terms of their environment that surrounded the company. The limitation of internal control and roles and responsibilities of relevant persons were listed as section "I 4" and "I 5"respectively. In I 5, the Exposure Draft of Standards clearly defined that management should be representatives of the enforcement organization, such as representative directors, chief executive officers, and so on.

Insert Table 3 here

\section{Changes of "II Assessment and Report on Internal Control over Financial Reporting"}

The definition of internal control over financial reporting was changed. In the Revised Preliminary Draft of Standards, internal control over financial reporting was defined as an internal control that was related to the reliability of financial reporting. The Exposure Draft of Standards changed "related to" to "necessary to ensure" which toned up the objective of internal control and management assessment of internal control (i.e., ensuring the reliability of financial reporting). The Exposure Draft of Standards divided II 2 into two subsections: (1) assessment of the effectiveness of internal control over financial reporting, and (2) determination of the scope of assessment in which it emphasized that management should determine the scope of assessment in the order of matters listed and explained the "presentation and disclosure of financial statements" with examples on how to determine the scope from the perspective of degree of quantitative and qualitative impact on financial statements. Risk factor was attached weight to the assessment of company-level control of II 3 (2) in which it addressed that management should sufficiently assess risks occurring inside/outside the organization and fully consider all matters that could have significant impact on overall financial reporting. The Exposure Draft of Standards added a new section of "Limitation of the Scope of Assessment" as II 3 (6), which stated the treatment when sufficient assessment procedures for a certain part of the internal control could not be performed due to unavoidable circumstances. In such cases, based on fully comprehending the impact on the financial reporting, management may exclude such procedures and assess the effectiveness of internal control over financial reporting. The methods for presenting the results of assessments on internal control were listed in II 4 (5) of the Exposure Draft of Standards, which included the statements that were effective, effective but excluding unperformed procedures due to unavoidable circumstances, and not effective and disclaimer of opinion.

\section{Changes of "III Audit on Internal Control over Financial Reporting"}

First, the statement of objective of internal control audit by financial statement auditors (III 1) was changed a lot. The Exposure Draft of Standards noted that the objective of internal control audit was to have external auditors express opinion on whether the management's internal control report fairly stated the results of the assessment in accordance with generally accepted assessment standards for internal control in all material respects. A new term of "internal control audit report" appeared to express the auditor's opinion. The criterion of issuance of unqualified opinion was that the auditor had obtained reasonable assurance that the internal control report by management did not include any material misstatements. On the relationship of the internal control audit and the financial statement audit, the Exposure Draft of Standards pointed out that the audit evidence obtained in the process of the internal control audit might be used as audit evidence for financial statement audit, and vice versa. As the supplement of report and remediation of material weakness in internal control of III 3 (5), the Exposure Draft of Standards requested that the external auditor should 
report the results of the internal control audit to the management, board of directors, corporate auditors or audit committee. When identifying deficiencies in the internal control, the external auditors must report to them by the final date of the Company Law Audit. On the auditor's report of III 4, the subsection of "disclaimer of opinions" was replaced by "exceptions to opinions". Compared to the Revised Preliminary Draft of Standards, the Exposure Draft of Standards fully considered the condition when external auditors identified inappropriate parts in the internal control report regarding the scope, procedures and results of the assessment determined by the management, they should express a qualified opinion with exceptive items unless they could conclude that the internal control report was significantly misstated. In such cases, they should express the opinion that the internal control report was not fairly stated.

\section{Toward Standards for Management Assessment and Audit concerning Internal Control over Financial Reporting}

\subsection{Summary of Comments on and Responses to Exposure Draft of Standards}

After the issuance of the Exposure Draft of Standards, about 40 comments from Japanese Institute of Certified Public Accountants (JICPA), various business groups, auditing firms, companies, and individuals had been received till August 31,2005 . The contents of comments and relevant responses were summarized and discussed in the $12^{\text {th }}$ Subcommittee meeting. Based on the materials distributed in the meeting, this study quantified the comments and responses to the Exposure Draft of Standards. The comment was summarized in terms of each item of the Exposure Draft of Standards and similar opinion was gathered. Table 4 shows the result of the quantification. Among the total item of 486, the statistical amount of comments represented the first is the comments on framework of internal control [I]. The comments on II and III rank the second and the third respectively. The comments on the preface stand the last. Responses to the comment are divided into four categories: comments that will be or have been treated with in the preface, comments that will be or have been handled in the Standards, comments that will be discussed in the Practice Standards and comments that have been discussed but are considered not necessary to response to. The result shows that $41.80 \%$ of the comments will be discussed in the Practice Standards. This indicates that the public has the strong will to need the practice standards and that the Subcommittee will meet the requirement.

\subsection{Difference between Standards and Exposure Draft of Standards}

After considering the public comments, the Exposure Draft was revised again and was finally issued as "Standards for Management Assessment and Audit concerning Internal Control over Financial Reporting" on December 8, 2005. The Standards varied the Exposure Draft of Standards from the following respects.

\section{Insert Table 4 here}

The significant changes of the framework of internal control lay in the definition of internal control and the description of IT component. Based on the comment of lacking description of relationship among four objectives in the definition and of the overlap of the basic components of internal control in I 1 (2) and I 2, the Standards described that the four objectives were distinct but overlapped each other, deleted I 1 (2) and clarified that internal control composed of four specific objectives and six specific basic components in the internal control definition. Thus, the statement of internal control definition became more complete and more appropriate for Japanese situation. The Standards deleted the section of I 3 and incorporated its contents which included the relationship between objectives and basic components and design and operation of internal control to the section of definition of internal control. One of the significant changes in basic components of internal control was the description on IT [I 2 (6)]. Based on the comment that it was difficult to understand the "use of IT", the Standards changed it into "response to IT" which was defined to establish appropriate policies and procedures in advance in order to achieve organizational objectives and respond appropriately to IT inside/outside the organization when performing business activities based on the policies and procedures. It also pointed out that response to IT was not always independent from other components of internal control. Of the contents of response to IT, the subsection of "response to IT environment" was newly added. It firstly defined the IT environment as the internal/external use of IT that was needed for the organization's activities, the level of IT penetration into the society and market, the use of IT for the company's transactions, and a series of information systems on which the organization selectively relied and others. It also pointed out that in order to achieve the objectives of internal control the organization should respond appropriately to IT environment based on the policies and procedures that were established in advance. The subsection of "use of IT" in the Exposure Draft of Standards was replaced by "use of IT and IT controls" which referred to the integral parts of other components of internal control and was assessed as a whole.

Assessment and report on internal control over financial reporting varied from the Exposure Draft of Standards as follows: (1) It added "in accordance with generally accepted assessment standards for internal control" when management assessed the internal control over financial reporting. The Exposure Draft of Standards defined material weakness as "a deficiency that has a reasonable possibility of having effect on financial reporting" while the Standards 
changed it into "...having a material effect...". Therefore, the statements were more accurate and scrupulous. (2) When addressing assessment of the effectiveness of internal control over financial reporting, the Standards added that the internal control over outsourced processes should be in the scope for the assessment. In order not to cause any misunderstanding, the term of "financial statement" and "report" were changed into "financial reporting" and "internal control report" in II 3 (4) and II 4 (2) respectively. In the supplementary information, a modifier of "pertaining to material weakness" was added after "remediation and other matters" which was implemented after the end of the fiscal year.

Little was modified on audit on internal control over financial reporting. In relation to objective of the internal control audit by financial statement auditors, based on the comment that the words of "internal control audit report" might give an impression as if the auditor would assess the effectiveness of internal control directly, the Standards explained that "such (auditor's) opinions on the internal control report are expressed in the audit report on internal control assessment ('internal control audit report' hereafter)" [III 1]. According to the comment, the Standards also defined the reasonable assurance as external auditors had obtained sufficient competent evidence to express such opinions.

\section{Toward Exposure Draft of Practice Standards for Management Assessment and Audit concerning Internal Control over Financial Reporting}

\subsection{Establishment of Working Group of Subcommittee}

During the course of publishing the Exposure Draft of Standards of July, 2005, many comments were received of which over 40 percent required to develop a set of practical guidance in order to implement the Standard (see table 4). Based on the comment, the Subcommittee decided to further insight into the practice standards for supporting the Standards in the $12^{\text {th }}$ Subcommittee meeting and established a special Working Group under the Subcommittee in the $13^{\text {th }}$ Subcommittee meeting. The Working Group would prepare the preliminary draft of the practice standards under the directions of the Subcommittee. Main considerations concerning the practice standards which came from the opinions received from the Exposure Draft of Standards and the make-up of the Working Group were discussed in the $13^{\text {th }}$ Subcommittee meeting. In order to establish a series of high quality guidelines for the practice, all 22 Working Group members were practitioners from different areas such as auditing, business, etc. so that they could represent interests of different groups. Mr. Takashi Hashimoto was appointed the chairman. As well as in the Standards, three parts were expected in the Practice Standards. The first was considerations on the basic framework of internal control. Based on the Japanese current condition, besides explaining each of the four objectives and six basic components, the Working Group planned to focus on and give a more detailed explanation on the safeguarding of the assets and response to IT which were added to COSO framework. Considerations on assessment and report on internal control over financial reporting ranked the second. According to the discussion of the Subcommittee meeting, the guideline for material weakness, determination of the scope of assessment, and so on would be considered sufficiently. The last considerations were audit on internal control over financial reporting. Main issues concerning the procedures on evaluation of the assessment of company-level controls and process-level controls, reporting and remediation of material weakness in internal controls, and etc. would be explained substantially.

\subsection{Exposure Draft of Practice Standards}

After establishment, the Working Group of the Subcommittee was actively engaged in preparing the practice standards. While fully reviewing existing internal control standards abroad and giving enough attention to the possible considerations in Japan, the Working Group established the practice standards which included three parts and discussed the contents in the $14^{\text {th }}$ and $15^{\text {th }}$ Subcommittee meetings respectively. On November 21, 2006, the FSA released the Exposure Draft titled the "Practice Standards for Management Assessment and Audit of Internal Control over Financial Reporting" (Exposure Draft of Practice Standards). The document was intended to supplement the "Standards for Management Assessment and Audit of Internal Control over Financial Reporting" (Standards), which was issued in December 8, 2005.

Consistent with the Standards, three parts were included in the Exposure Draft of Practice Standards. In the part of "I Basic Framework of Internal Control", except for four parts in the Standard of 2005, a new section titled "Establishment of Internal Control over Financial Reporting" was added in the Exposure Draft of Practice Standards of 2006. It described the key considerations and process of establishing internal control over financial reporting. The section of key considerations listed key points to consider when establishing internal control over financial reporting according to the internal control basic framework. The process section illustrated the general steps to prepare for an assessment of internal control and to report the result of the assessment: (1) determination of basic plan and policy, (2) understanding of state of internal control design, and (3) a response to and remediation of identified deficiencies. The supplement of this part provided concrete guideline for management establishing, assessment and report internal control over financial reporting. Response to IT, as the sixth component of internal control, was an important part in the Exposure Draft of Practice Standards as well as in the Standards. The "Response to IT" component included that: (1) "response to IT environment" described the requirement to understand and response to the IT environment surrounding the organization. 
Factors surrounding the IT environments that were common to many organizations were listed as examples, such as IT pervasiveness into society and markets, stability of IT-based information system, and the like; (2) "use of IT and IT controls" included two subsections of "use of IT" and "IT controls". The former explained how organizations could use IT to enhance the effectiveness and efficiency of other components of internal control and provided special examples to support it. The latter listed examples of IT control objectives for achieving the organizational objectives. To achieve IT control objectives IT general controls and IT application control were required.

On the part of "II Assessment and Report on Internal Control over Financial Reporting", the Standards included a section of "4 Management's Report on Internal Control over Financial Reporting" while the Exposure Draft of Practice Standards did not included such a section. Therefore, there were three sections in this part. First, the Exposure Draft of Practice Standards defined and clarified the scope of financial reporting and provided the concrete guidelines for determining material weakness. The Standards defined the financial reporting as "external reporting that both relate to financial statements and disclosure information and others that could have a material effect on the reliability of financial statements" [II 1 (1)]. The Exposure Draft of Practice Standards further explained that financial statements were the consolidated financial statements while "disclosure information and others that could have a material effect on the reliability of financial statements" was defined as disclosure information and others (except financial statements) included in the annual report and examples were also listed to identify such information [II 1 [1]]. Consequently, the disclosure information and consolidated financial statements compose the financial reporting. When determining whether a control deficiency is a material weakness, both quantitative and qualitative facts must be considered. The Exposure Draft of Practice Standards stated the concrete index (a percentage of consolidated total assets, consolidated sales, consolidated income before income taxes and minority interests) and the acceptable threshold $5 \%$. This will be conductive to the performance of the Standards. Second, the Exposure Draft of Practice Standards explained management assessment of internal control over financial reporting, and scope of assessment. On the assessment of the company-level controls, aiming at the regulation that "the assessment of internal control over financial reporting effectiveness should be, in principle, performed on a consolidated basis" in the Standards [II 2 (1)], the Exposure Draft of Practice Standards stated when determining the scope of assessment, the consolidated subsidiaries (including partnership), equity method affiliated companies and foreign subsidiaries would be subject to the process. It specially stipulated the assessment of outsourced process, including scope of assessment of outsourced processes and assessment of internal controls over outsourced processes such as validation via sampling, use of service organization assessment results, etc. Based on the assessment of company-level controls, the Exposure Draft of Practice Standards provided for the procedures for determining the scope of assessment of business processes: selecting significant locations or business units, identifying business processes to be assessed, and communication with external auditor(s). Third, the Exposure Draft of Practice Standards stipulated concrete method of assessing internal control over financial reporting. It explained the use of top-down approach in detail under which management should first assess internal controls that had a material impact on overall consolidated financial reporting (i.e., company-level controls) and, based on the results, assess the internal control incorporated into business processes (i.e., process-level controls). On the assessment of company-level controls, the Exposure Draft of Practice Standards provided 42 assessment items [Exhibit 1], most of which are similar to the items listed in the "Principles Evaluation Matrix" of COSO's Internal Control over Financial Reporting - Guidance for Smaller Public Companies issued in July 2006. Four steps were provided to assess the process-level controls based on the result of assessment of company-level controls. The Exposure Draft of Practice Standards also provided guidance on determining the effectiveness of internal control over financial reporting.

The part of "III Audit on Internal Control over Financial Reporting" included five sections. Section "III 1 Objective of Internal Control Audit" emphasized that external auditors should express their opinions on the management's assertions that were the assessment results of internal control effectiveness but not directly evaluate the design and operating effectiveness of internal controls. External auditors' simultaneous provision of internal control audit service and non-audit certification services was restricted in section "III 2 Relationship between the Internal Control Audit and the Financial Statement Audit". The section of "Performance of the Internal Control Audit" in the Standards was divided into two sections in the Exposure Draft of Practice Standards. One was "III 3 Audit Planning and the Scope of Assessment" and the other was "III 4 Performance of the Internal Control Audit". The matters to be considered for audit planning for internal control audit and for assessing the appropriateness of scope of assessment were listed in the former while the concrete evaluation of assessment of company-level controls and process-level controls were explained in the latter. The last section was "III 5 Auditor's Report", which described the expression of an opinion including exceptions to opinions.

\section{Toward Council Opinions of 2007}

After the Exposure Draft of Practice Standards was published in November 21, 2006, the FAS requested comments from the public until December 20, 2006. During this period 190 comment letters were received, which consisted of 59 from corporations (including various groups) and 131 from individuals (including CPA, lawyer and others). In the $16^{\text {th }}$ Subcommittee meeting, based on the comments, BAC revised the Exposure Draft of Practice Standards and put it 
together with the Standards issued in December 8, 2005. Thus "On the Setting of the Standards and Practice Standards for Management Assessment and Audit concerning Internal Control over Financial Reporting (Council Opinions)" (Council Opinions of 2007) ${ }^{[9]}$ came into being.

\subsection{Summary of Comment Letters}

According to minutes of $16^{\text {th }}$ Subcommittee meeting, the comments were divided into overall comments and comments for the individual items [see table 5]. There were four categories in the comments for the individual items: (1) necessary responses in the Practice Standards, (2) things that should be discussed in government ordinances, Cabinet Office regulations, and etc., (3) things difficult to respond or not necessary to respond, and (4) other comments. The specific comments of (3) were not listed in the table since the Subcommittee thought that it was difficult or not necessary to respond to. For example, the comment pointed out that in the II 1 [2] A "a. determining quantitative materiality", numerical criterion of consolidated income before income taxes had been set. Therefore, consolidated sales and other related part of materiality in the Practice Standards should also be set. However, the Subcommittee argued that the guideline for determining material weakness could not be presented uniformly because it varied based on the environment or business nature of the companies. In the Practice Standards, considering the convenience of the practice and possibility of generalization to some degree on consolidated income before income taxes, approximate $5 \%$ was set. Referring to this about 5\% criterion, other items should be judged individually in terms of impact on reliability of financial reporting. On the comments of (4), the Subcommittee explained its way of thinking by a table in the meeting.

\subsection{Revised Exposure Draft of Standards and Council Opinions of 2007}

Based on the comments, BAC revised the Exposure Draft of Practice Standards and put it together with the Standards issued in December 8, 2005 to form the Council Opinions of 2007. The contents of the Council Opinions of 2007 included three parts: the introduction, the Standards, and Practice Standards for Management Assessment and Audit concerning Internal Control over Financial Reporting (the Practice Standards).

\subsubsection{Introduction of the Council Opinions of 2007}

This was the explanation part of the Council Opinions of 2007. General background of discussions and structure and contents of the Standards and the Practice Standards were stated. The contents of the Standards basically followed those of the Standards of December 8, 2005 and some amendment was made according to the progress afterwards. The contents of the Practice Standard were a new section in this part, including basic framework of internal control, assessment and report on internal control over financial reporting, and audit on internal control over financial reporting. The effective date was also added in this part.

Insert Table 5 here

\subsubsection{Main Changes in the Standards}

Compared to the Standards of December 8, 2005, there is no substantial modification in the Standards part except some small changes. For example, in the paragraph 2 of II 2 (2), "management should, first based on the determination of significant locations or business units, examine the scope of assessment ...", "first" was deleted. In the paragraph 2 of III 3 (4), “... external auditors must obtain audit evidence for key audit objectives, such as existence or occurrence, completeness, rights and obligations, valuation, allocation, presentation and disclosure, authority and responsibility, and record", "authority and responsibility, and record" were deleted. In the III 4 (6), a new additional information was added which was "[4] The scope for which sufficient assessment procedures could not be performed and relevant reasons, when external auditors judge that the management could not perform a certain part of the assessment procedures due to unavoidable circumstances and therefore express an unqualified opinion".

\subsubsection{Main Changes in the Practice Standards}

Based on the necessary responses in the Practice Standards of comments for the individual item which were discussed in the $16^{\text {th }}$ Subcommittee meeting, the Practice Standards were revised as follows.

Guidelines for Determining Material Weakness. In "II 1 [2] Guidelines for Determining Material Weakness", two paragraphs were added to address that the guideline for determining material weakness could not be presented uniformly since it varied according to the environment or business nature of the companies. Simultaneously, it emphasized that the material weakness, basically, should be judged in terms of impact on the likelihood and impact of misstatements related to financial reporting.

Determining the Scope of Assessment of Business Processes. On the method for determining business process scope, aiming at the comment of lacking consistency between "based on significant locations or business unit" in the Exposure Draft of Practice Standards [II 2 (2)] and "based on important accounts" in the Standards(Note 4), the BAC deleted "first" and added "based on the determination of significant locations or business units". Thus, the Practice Standards clarified the beginning from the selection of an important business unit base when determining business process scope. Based on the comment that the scope of assessment of period-end financial reporting should be clarified from a 
company-wide perspective, the repeated words such as "in the business processes" and "all the business units" were deleted in "II 2 (2) Determination of the Scope of Assessment". It added "... to be assessed from the company-wide perspective" to the note when giving example tasks of period-end financial reporting reprocess. Therefore, it was clear that the difference of this illustration from others was to assess the period-end financial reporting reprocess (primarily performed by accounting department) from the company-wide perspective. On selecting significant locations or business units, in accordance with the comment that it did not specified whether "a certain ratio of consolidated sales" was the sales after elimination of inter-company transaction or that of before elimination of inter-company, in Note 2 of II 2 (2)[1], "certain ratio may be, for example, two-thirds of total sales on a consolidated basis and others" was specified. It also added "instead of two-thirds of total sales on a consolidation basis, a certain ratio may be applied to sales before elimination of inter-company transactions" to the end of the note. In identifying business processes to be assessed, in terms of the comment whether the cost accounting process should be included in the business process to the inventory, a paragraph was newly added to the II 2 (2) [2], which noted that management was not generally required to assess the entire costing process but enough of the process for the end-of-period inventory valuation within the costing process.

Company-level Controls and Process-level Controls. According to the comment that the difference between "particularly effective" and "effective" should be clarified when simple assessment procedure was taken in consideration to judge the "particularly effective" of company-level control, in II 3 (2) [3] "... if the company-level controls 'can be judged as particularly effective', the assessment of process-level controls may be simplified...", "can be judged as particularly effective" was revised to "are assessed as operating effectively". Therefore, the problem of difference or inconsistency between the two words was resolved. The example that "deficiencies existing in internal controls over IT relating to its assessing limitation were left unimproved" was pointed out to be improper as an example of company-level control deficiency. Based on that comment, the BAC revised it into "deficiencies existing in internal controls over IT relating to financial reporting are left unimproved". In the Exhibit 3 Risk Control Matrix (Example), in response to the comment whether it was an appropriate example since "shipping of different goods or amount from the shipment request" in the "controls" of "shipping" might not necessarily lead to the misstatement, "shipping of different goods or amount from the shipment request" was revised to "shipping of a smaller number of goods than requested". According to the comment of clarifying the external auditor's treatment when sufficient assessment procedures could not be performed for a certain part, BAC explained it in detail in III 5 (2). External auditors should issue an unqualified opinion in the internal control audit report if they could conclude management's assessment of internal control over financial reporting was fairly stated in all material respects in conformity with generally accepted assessment standards for internal control, except that sufficient assessment procedures could not be performed due to unavoidable circumstances. In such cases, the scope that the management excluded from the assessment due to unavoidable circumstances and relevant reasons must be added to the internal control audit report. As additional information, it was also added to III 5 (3).

\section{Summary}

Along with the heightening of improper practices in recent years, the BAC realized the importance of enhancing internal control and established the Subcommittee and its Working Group to develop internal control standards. Based on fully understanding the existing internal control standards, especially the standards in the United States, and sufficiently considering Japan's concrete condition, the Subcommittee held 16 special meetings in which the representatives both in theory and in practice had heated discussions and amended the drafts with careful considerations again and again. As a result, after over two years of effort, on February 15, 2007 the BAC released the standards and the practice standards for management assessment and audit concerning over financial reporting that would conform to the situation in Japan. It is expected that the management risk and audit risk can be further reduced by enhancing the effectiveness of internal control over financial reporting after the Council Opinions of 2007 become effective.

\section{References}

Business Accounting Council of the Financial Services Agency. (2002). Auditing Standard, Business Accounting Council of the Financial Services Agency. [Online]A vailable: http://web.kyoto-inet.or.jp/people/fujino/auditst.doc, March 15, 2006. (Japanese)

Business Accounting Council of the Financial Services Agency. (2005). Auditing Standard, Business Accounting Council of the Financial Services Agency. [Online] Available: http://www.k3.dion.ne.jp/ afujico/kaikei/kansa/kijyunh171028.htm, July 9, 2007. (Japanese)

Business Accounting Council of the Financial Services Agency. (2005). Exposure Draft of Standards for Management Assessment and Audit concerning Internal Control over Financial Reporting. (Japanese)

Business Accounting Council of the Financial Services Agency. (2005). Standards for Management Assessment and Audit concerning Internal Control over Financial Reporting. (Japanese)

Business Accounting Council of the Financial Services Agency. (2006). Exposure Draft of Practice Standards for 
Management Assessment and Audit concerning Internal Control over Financial Reporting. (Japanese)

Business Accounting Council of the Financial Services Agency. (2007). On the Setting of the Standards and Practice Standards for Management Assessment and Audit concerning Internal Control over Financial Reporting (Council Opinions). (Japanese)

Business Accounting Council of the Ministry of Finance. (1991). Auditing Standard, Working Rules of Audit Procedures of Field Work and Working Rules of Audit Procedures in Reporting, Business Accounting Council of the Ministry of Finance. (Japanese)

Internal Control Subcommittee of Business Accounting Council of the Financial Services Agency 2005-2007, 1st-16th Meetings of Internal Control Subcommittee. [Online] Available: http://www.fsa.go.jp/singi/singi_kigyou/top_gijiroku.html\#naibu. May 6, 2007. (Japanese)

Special Committee of Japanese Accounting Association. (1970). Research on Internal Control over Financial Reporting. (Japanese)

\section{Notes}

Note 1. The Subcommittee was established by the BAC and was responsible for establishing standards of internal control.

Note 2. In the 6th Subcommittee meeting, the effectiveness of internal control over financial reporting referred to the condition that no deficiency that had a reasonable possibility of material effect on financial reporting (i.e., material weakness) existed in the internal control.

Note 3. In the 9th Subcommittee meeting, practitioner representatives in different areas as witnesses stated their opinions on the assessment and audit standards of internal control over financial reporting. They were Norio Hagiwara (Representative Director of the Mamezou Corporation), Hiroshi Mikitani (President and Representative Director of the Rakutenn Corporation), Tetsuo Mazuda (Vice President of Japan Federation of Bar Association), Kazuo Tezsuka (Lawyer), Hiromichi Oogawa (Standing Director of Japan Corporate Auditors Association), and Yukihisa Kannda (Managing Director of the Institute of Internal Auditors-Japan).

Note 4. The Standards II 2 (2) addressed "Management should first examine the scope of assessment for these items from the perspective of their degree of quantitative and qualitative impact on the presentation and disclosure of financial statements." At the same time, with regard to "presentation and disclosure of financial statements", it took the determination of important account as example in the note. 
Table 1. Proceedings toward Exposure Draft of Standards

\begin{tabular}{cl}
\hline $\begin{array}{c}\text { Subcommittee } \\
\text { meetings }\end{array}$ & \multicolumn{1}{c}{ Main contents } \\
\hline $1^{\text {st }}$ & Necessity of setting standards of internal control \\
$2^{\text {nd }}$ and $3^{\text {rd }}$ & Existing internal control standards and Japanese practice of internal control \\
$4^{\text {th }}$ & Key points of setting standards of internal control \\
$5-8^{\text {th }}$ & Preliminary Draft of Standards \\
$9^{\text {th }}$ & Statement of witness's opinions \\
$10-11^{\text {th }}$ & Revised Preliminary Draft of Standards and Exposure Draft of Standards
\end{tabular}

Source: Minutes of $1^{\text {st }}-11^{\text {th }}$ Internal Control Subcommittee Meetings

Table 2. Key Points of Setting Assessment and Audit Standards

\begin{tabular}{|c|c|}
\hline Code & Key Points \\
\hline I & Framework of internal control \\
\hline A & Necessity of international explanation besides Japanese actual condition \\
\hline B & Development of objective and components based on COSO Report \\
\hline $\mathrm{C}$ & Besides external report, internal report is also required (e.g., UK and Canada) \\
\hline $\mathrm{D}$ & Appropriate form of framework (U.S. COSO or UK Framework) \\
\hline $\mathrm{E}$ & Business scale \\
\hline II & Assessment and audit of internal control \\
\hline A & Objective of assessment and audit \\
\hline $\mathrm{a}$ & Understanding of company-level control \\
\hline $\mathrm{b}$ & Deterrent of management fraud \\
\hline c & Management confirmation was limited to reliability of financial reporting (COSO) \\
\hline d & Expansion of assessment scope from financial reporting to annual report \\
\hline $\mathrm{B}$ & Method of assessment and audit \\
\hline $\mathrm{a}$ & Audit (the U.S.) or review (UK and France) \\
\hline $\mathrm{b}$ & Benefit and cost of process assessment and audit \\
\hline $\mathrm{c}$ & Consolidated base or separate base \\
\hline d & Corporate auditors or audit committee and external auditors \\
\hline e & Position of audit report of corporate auditors in Securities and Exchange Law \\
\hline f & IT control \\
\hline III & Report of assessment and audit \\
\hline A & Direct reporting or indirect reporting \\
\hline B & External auditor and management on setting internal control \\
\hline
\end{tabular}

Source: Minutes of $4^{\text {th }}$ Internal Control Subcommittee Meeting ${ }^{[5]}$ 
Table 3. Outline of Exposure Draft of Standards

\section{Basic Framework of Internal Control}

A Definition of Internal Control

B Basic Components of Internal Control

C Design and Operation of Internal Control*

D Limitations of Internal Control

E Roles and Responsibilities of Personnel Who Perform Internal Control

\section{Assessment and Report on Internal Control over Financial Reporting}

A Definitions Related to the Assessment of Internal Control over Financial Reporting

B Assessment of Internal Control over Financial Reporting, and Scope of Assessment

C Method of Assessing Internal Control over Financial Reporting

D Management's Report on Internal Control over Financial Reporting

\section{Audit on Internal Control over Financial Reporting}

A Objective of the Internal Control Audit by Financial Statement Auditor

B Relationship between the Internal Control Audit and the Financial Statement Audit

C Performance of the Internal Control Audit

D Auditor's Report

* This section was deleted in the Standards issued in the December 8, 2005.

Source: Exposure Draft of Standards for Management Assessment and Audit concerning Internal Control over Financial Reporting

Table 4. Summary of Comments on and Responses to Exposure Draft of Standards

\begin{tabular}{l|l|l|l|l|l|l|l|l|l}
\hline \multirow{2}{*}{ Section } & \multirow{2}{*}{ Item } & \multicolumn{2}{l}{ Responses to comments } \\
\cline { 3 - 10 } & & \multicolumn{2}{l|}{ Preface } & \multicolumn{2}{l|}{ Standards } & \multicolumn{2}{l}{ Practice Standards } & \multicolumn{2}{l}{ No response } \\
\cline { 3 - 10 } & & Number & $\%$ & Number & $\%$ & Number & $\%$ & Number & $\%$ \\
\hline Preface & 98 & 32 & 32.65 & 2 & 2.04 & 31 & 31.63 & 33 & 33.68 \\
I & 142 & 18.16 & 12.79 & 36 & 25.35 & 25.34 & 17.85 & 62.5 & 44.01 \\
II & 130 & - & - & 11.33 & 8.72 & 86.83 & 66.79 & 31.84 & 24.49 \\
III & 116 & - & - & 3 & 2.59 & 60 & 51.72 & 53 & 45.69 \\
Total & 486 & 50.16 & 10.32 & 52.33 & 10.77 & 203.17 & 41.80 & 180.34 & 37.11 \\
\hline
\end{tabular}

Source: Minutes of $12^{\text {th }}$ Internal Control Subcommittee Meeting

Note:

Preface: based on the comment, responses will be or has been done in the Preface.

Standards: based on the comment, responses will be or has been done in the Standards.

Practice Standards: the contents that should be regulated in the Practice Standards.

No response: the comment that has been discussed but no response will be or has been done and the reasons why.

Source: Minutes of $16^{\text {th }}$ Internal Control Subcommittee. 
Table 5. Summary of Comments on Exposure Draft of Practice Standards

\section{Overall Comments}

1. It is expected to clear away swallowing US-SOX on trust and to particularly evaluate the points which have presented in courteous draft based on the characteristics of Japan.

2. It is welcome for the manager to present the concrete samples or numeric examples of the pending problems when narrowing the scope.

3. Is it cruel to deal the small and medium-sized companies with the same standards?

4. The auditor should be requested not to become conservative.

5. It should be a strict standard as a whole.

\section{Comments for the Individual Items}

\section{Necessary responses in Practice Standards}

a. Which is better for a certain ratio of consolidated sales, the sales before offsetting or after offsetting?

b. On the method for determining business process scope, it lacks of consistency between the Standards and Practice Standards.

c. The scope of assessment of period-end financial reporting should be clarified from a company-wide perspective.

d. Is the cost accounting process included in the inventory business process?

e. The example that rises as company-level internal control was improper in "There is deficiency in IT-based internal control due to its assessing limitation and it has been left without being improved" (II 3 (4) [1] C d).

f. Is it an appropriate example that in the "Risk Control Matrix (Example)", "shipping of different goods or amount from the shipment request" in the "controls" of "shipping" might not necessarily lead to the misstatement?

g. The treatment in the audit should be clarified when the scope of the assessment is restricted by unavoidable circumstances.

h. The difference between "particularly effective" and "effective" should be clarified when simple assessment procedure was taken in to judge "particularly effective" of company-level control.

2. Things that should be discussed in government ordinances, Cabinet Office regulations, and etc.

a. Items and forms of internal control report and internal control audit report should be described clearly.

b. The treatment of the registrants of the U.S. SEC which should follow Section 404 of SOX should be clearly addressed.

c. How to deal with subsidiaries of overseas?

d. The treatment of the subsidiary should be specified when the accounting period was different.

\section{Things difficult to respond or not necessary to respond.}

\section{Other comments}

